\title{
The effect of the degree of isolation of alder tussocks on the activity and diversity of epigeic invertebrates ${ }^{*}$
}

\section{Wpływ stopnia izolacji kęp olsowych na aktywność i różnorodność epigeicznych bezkręgowców}

\author{
Izabella Olejniczak, Paweł Boniecki, Janusz Uchmański \\ Institute of Ecology and Bioethics, Cardinal Stefan Wyszyński University in Warsaw, Poland \\ ORCID: IO https://orcid.org/0000-0003-4746-7874; PB https://orcid.org/0000-0003-0681-5246; \\ JU https://orcid.org/0000-0001-8087-8371・i.olejniczak@uksw.edu.pl
}

\begin{abstract}
Activity and diversity of epigeic invertebrates were studied in 2004 in alder wood (Alnus glutinosa-Carex elata association). The following chosen: fragment of alder wood and 23 alder tussocks with average surface of $0.27 \mathrm{~m} 2$. Also, 16 artificial tussocks were installed: 4 of them were the same size as natural ones, and other 12 were smaller, $0.1 \mathrm{~m} 2$ in size. The average height of tussock was $0.4 \mathrm{~m}$. Distance between individual tussocks varied from 1 to $2 \mathrm{~m}$. Tussocks were placed 3, 5, 7,9 and $11 \mathrm{~m}$ from the fragment of the alder wood. The material was collected using pitfall traps. Samples were taken every 7 or 14 days twice in the season: when tussocks were or were not isolated by water. The distance from the alder wood did not influence on activity and diversity of epigeic invertebrates on tussocks. Saprophagous: Isopoda and Collembola and predators: Araneae and Carabidae were the most abundant in the samples.
\end{abstract}

Keywords: alder wood, epigeic invertebrates, isolation

Streszczenie: W 2004 roku badano aktywność i różnorodność epigeicznych bezkręgowców w lesie olsowym (zbiorowisko Alnus glutinosa-Carex elata). Wybrano: fragment olsu oraz 23 kępy olsowe, o średniej powierzchni 0,27 m2. Zainstalowano także 16 sztucznych kęp: 4 z nich były tej samej wielkości co naturalne oraz 12 mniejszych, o powierzchni 0,1 m2. Przeciętna wysokość kęp wynosiła 0,4 m. Odległości między poszczególnymi kępami wahały się od 1 do $2 \mathrm{~m}$. Kępy były położone 3, 5, 7, 9 i $11 \mathrm{~m}$ od fragmentu olsu. Materiał zbierano stosując pułapki glebowe. Próbki pobierano co 7 lub 14 dni, dwukrotnie w sezonie: gdy kępy były izolowane lub nie były izolowane przez wodę. Odległość od olsu nie wpływała na aktywność i różnorodność epigeicznych bezkręgowców na kępach. W próbkach najliczniej występowały saprofagi: Isopoda i Collembola oraz drapieżniki: Araneae i Carabidae.

Słowa kluczowe: ols, epigeiczne bezkręgowce, izolacja

\section{Introduction}

Biodiversity has become a key issue in ecology in recent decades. A steady decline in the number of species of organisms on Earth is observed, mainly due to human activities. Ecosystems are being simplified or fragmented.

There is little work analysing invertebrates found in "natural" environments that are fragmented or periodically isolated. An example is the alder wood, flooded in the spring and early summer so that the alder tussocks are insulated with water, to which only a few works have been attributed (Stachurski 1968; Olejniczak 1998). Understanding the biodiversity and functioning of the

\footnotetext{
" This article was originally published in Polish as Olejniczak, Izabella, Paweł Boniecki, i Janusz Uchmański. 2011. "Wpływ stopnia izolacji kęp olsowych na aktywność i różnorodność epigeicznych bezkręgowców." Studia Ecologiae et Bioethicae 9(3): 37-46. The translation of the article into English was financed by the Ministry of Science and Higher Education of the Republic of Poland as part of the activities promoting science - Decision No. 676/P-DUN/2019 of 2 April 2019. Translation made by GROY Translations.
} 
"natural" environments which are fragmented and periodically isolated, such as the alder wood, can contribute to the development of strategies for the protection of man-made environments. The findings presented are part of research into how invertebrates function, how they interact and how they spread in periodically isolated environments.

The purpose of the study was to investigate how the degree of environmental insulation affects invertebrates. It has been assumed that as the dense fragment of alder wood moves away, the catching effectiveness and diversity of invertebrates on adjacent tussocks would decrease.

\section{Study area and methods}

The research was conducted in the area of the Strict Protection Area "Sieraków" in the Kampinos National Park near Warsaw $\left(52^{\circ} 31^{\prime} \mathrm{N} ; 20^{\circ} 57^{\prime} \mathrm{E}\right)$. The study covered a 30 to 40-year-old alder forest, belonging to the $\mathrm{Al}$ nus glutinosa-Carex elata plant association.

In 2004, a fragment of the alder wood and the adjacent 23 alder tussocks periodically isolated by water were selected. The tussocks selected for the study had steep sides, so that their surface remained unchanged, regardless of the water level. The average surface area of the tussock (calculated from the formula for the Ellipse's surface, less the surface of the cross-section area of the tree trunk at ground level) was $0.27 \mathrm{~m}^{2}$, while the average height was $0.4 \mathrm{~m}$. The distances between the adjacent tussocks ranged from 1.0 to $2 \mathrm{~m}$. The distance between the alder wood fragment and the nearest tussocks was $3 \mathrm{~m}$, while the furthest $11 \mathrm{~m}$.

In addition to natural tussocks, 16 artificial tussocks were also installed, including 4 large ones, with a surface of $0.27 \mathrm{~m}^{2}$, the same as natural tussocks, and 12 small ones, with a surface of $0.1 \mathrm{~m}^{2}$. The artificial tussocks were made of styrofoam and fastened in a movable way so that they would always float on top of the water.

The tussocks of sedges, found between the studied alder tussocks have been removed. The species found on all tussocks, dominant on nearly half of them, was an elongated sedge Carex elongata.

The carbon and nitrogen content of the soil of the alder forest fragment, tussocks, and between tussock area, determined by the $\mathrm{C} / \mathrm{N}$ ratio, varied between $12-16$. Furthermore, based on Stachurski's (1968) research, it is known, that the organic matter content available on tussocks decreases from spring to autumn, which is a constant phenomenon. This is associated with autumn leaves fall and their decomposition over the following months.

The water level in the studied alder wood was maintained until mid-July. In spring, water dropped slowly, in late summer rapidly (Fig. 1).

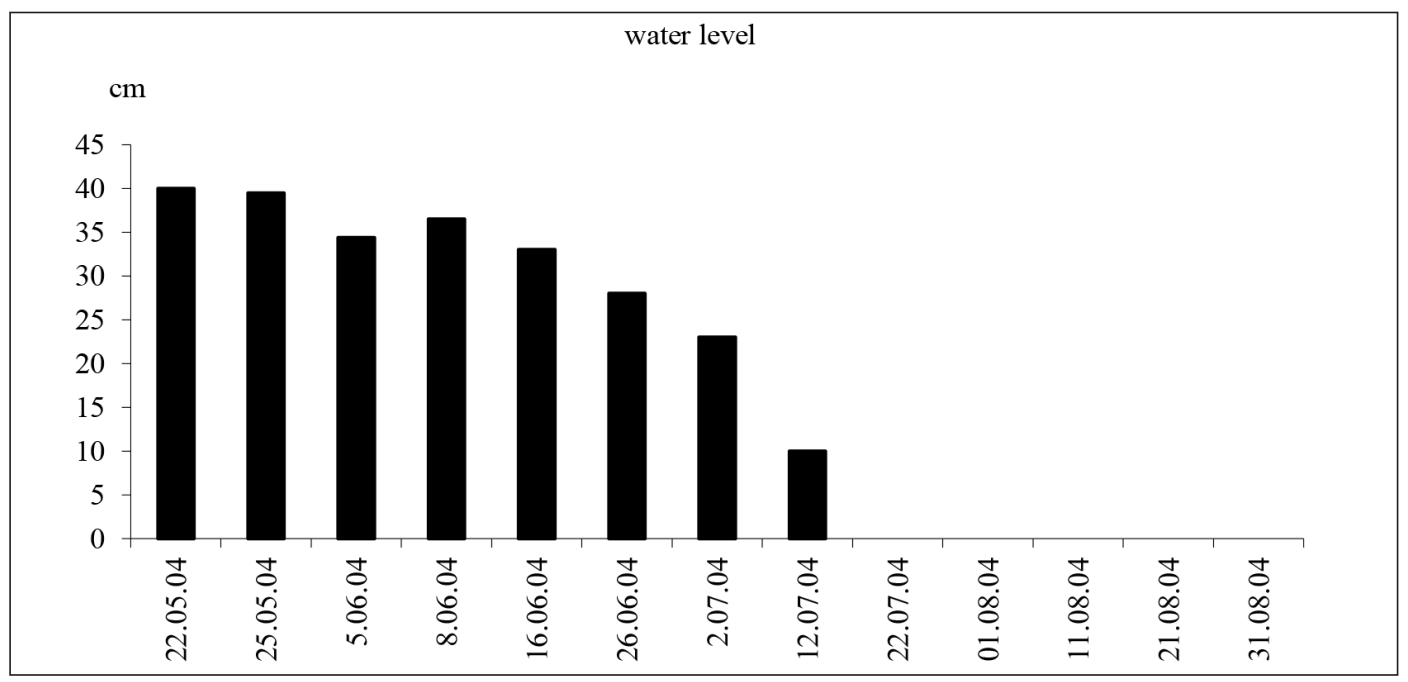

Fig. 1. Water level maintained between tussocks during the study period, 2004. 
The study used the Barber trap method, widely applied in the catches of epigeic fauna. Although the method is not a quantitative method, it does allow simultaneous testing in multiple environments. It informs about the mobility of individuals and the ability to penetrate study environments. Thus, the number of individuals per day and per trap, referred to as catching, is given. Plastic containers, $7 \mathrm{~cm}$ deep and $1.4 \mathrm{~cm}$ in diameter, which were filled with ethylene glycol with the addition of a detergent, were used as traps. 3 traps were set in each tussock. In the area of the alder wood adjacent to tussocks, 20 of such containers were placed. Besides, 20 traps were set between the tussocks when there was no water present. The material was collected twice a season, in weekly or two-week periods, when the tussocks were surrounded by water (9-16.06; 16-26.06; 26.06.-2.07), and during the period when there was no water present $(6-17.07 ; 17$ 30.07. 26.07-5.08). The collected animals were divided into taxa of varying rank and stored in $75 \%$ alcohol. Only the beetles were divided into families, other insects were categorized into orders, while the rest of invertebrate - taxa of a higher rank.

The Shanonn-Wiener (Shanonn and Wiener 1963) - H' diversity index was used to analyse the variety of invertebrate groups. The catching of individual invertebrate taxa was used to calculate the
$H^{\prime}$ index value. Hutcheson's (1970) test was used to determine the significance of the H' index differences calculated for specific invertebrate groups.

For statistical analysis of the material, nonparametric tests were used: the Wilcoxon rank-sum test, to compare differences in average invertebrate catchings, and the ANOVA Kruskal Wallis test, to analyse the effect of distance from an alder wood fragment and tussock sizes on the catching and diversity of invertebrate.

\section{Results and discussion}

\subsection{Fragment of alder wood and adjacent alder tussocks}

The average activity of invertebrates was higher in the alder wood fragment than in the tussocks studied, both during the period when the water isolated the tussocks, as well as during the period when it was not present between them (Table 1). However, no significant differences in invertebrate catchings were observed between individual tussocks. The size of the tussocks did not affect the activity of the invertebrate, neither when the tussocks were isolated by water, nor during the absence of such isolation. The same was noted for the distance of tussocks from the alder wood fragment.

In the period when the water did not isolate the tussocks, the catching of invertebrates between them was similar to that recorded on isolated tussocks (Table 1 ).

Table 1. Average catchings (number of individuals/day/trap) of invertebrates in a fragment of unaltered alder, on alder tussocks isolated and non-isolated by water and between non-isolated tussocks.
Alder wood fragment
Tussocks
Area between
tussocks

$\begin{array}{lccc}\text { Water between tussocks } & 4.7 \pm 1.6^{\mathrm{a}, \mathrm{d}} & 1.5 \pm 0.5^{\mathrm{b}} & - \\ \text { No water between tussocks } & 3.6 \pm 1.3^{\mathrm{e}} & 0.4 \pm 0.3 & 1.2 \pm 0.9^{\mathrm{c}}\end{array}$

a - significant differences in catchings during isolation in alder wood fragment and tussocks, $\mathrm{p}=0.003$

$\mathrm{b}$ - significant differences in catchings on isolated and non-isolated tussocks, $\mathrm{p}=0.0001$

c - significant differences in catchings in areas between isolated and non-isolated tussocks, $\mathrm{p}=0.003$

$\mathrm{d}$ - significant differences in catchings in the alder wood fragment during isolation and lack thereof, $\mathrm{p}=0.007$

e - significant differences in catchings during the absence of insulation in the alder wood fragment and on tussocks, $\mathrm{p}=0.0001$ 
Sixteen invertebrate taxa have been identified in the alder wood study. Among those found in the alder wood fragment and tussocks dominated four taxa: isopods (Isopoda), springtails (Collembola) - saprophages, and the family of carabid beetles, (Carabidae), and spiders (Araneae) - predators (Fig. 2 and 3). The propor- tion of these invertebrate groups varied, depending on the degree of isolation of the tussocks. During the floods, isopods dominated invertebrate groups, both in the alder wood and in the tussocks (Fig. 2 ), whereas springtails dominated during the period when water was not present between tussocks (Fig. 3).

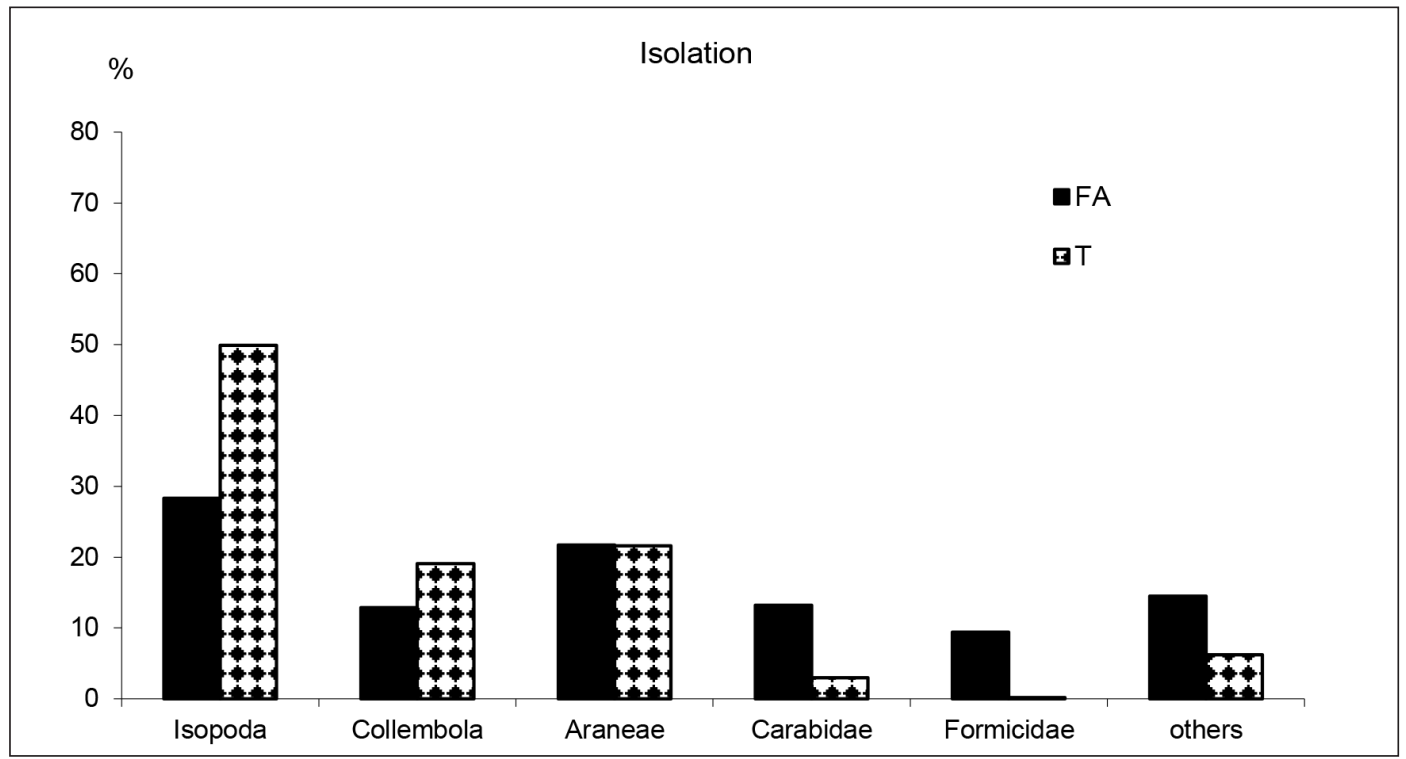

Fig. 2. The share of individual taxa (see Methods) in invertebrate assemblages in the alder wood fragment (FA) and on tussocks (T), when the latter are isolated by water.

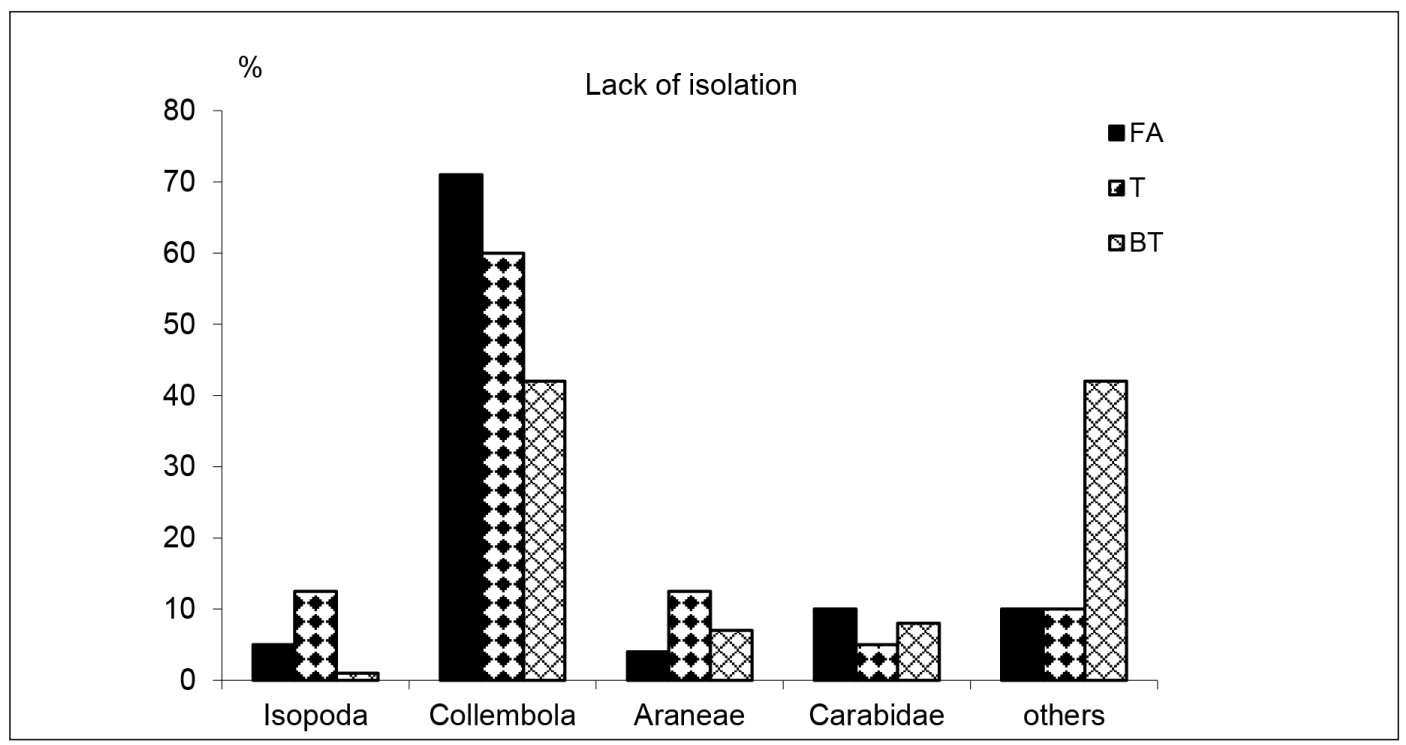

Fig. 3. The share of individual taxa (see Methods) in invertebrate assemblages in the alder wood fragment (FA), on tussocks ( $T$ ) and between tussocks (BT) when there is no water between them. 


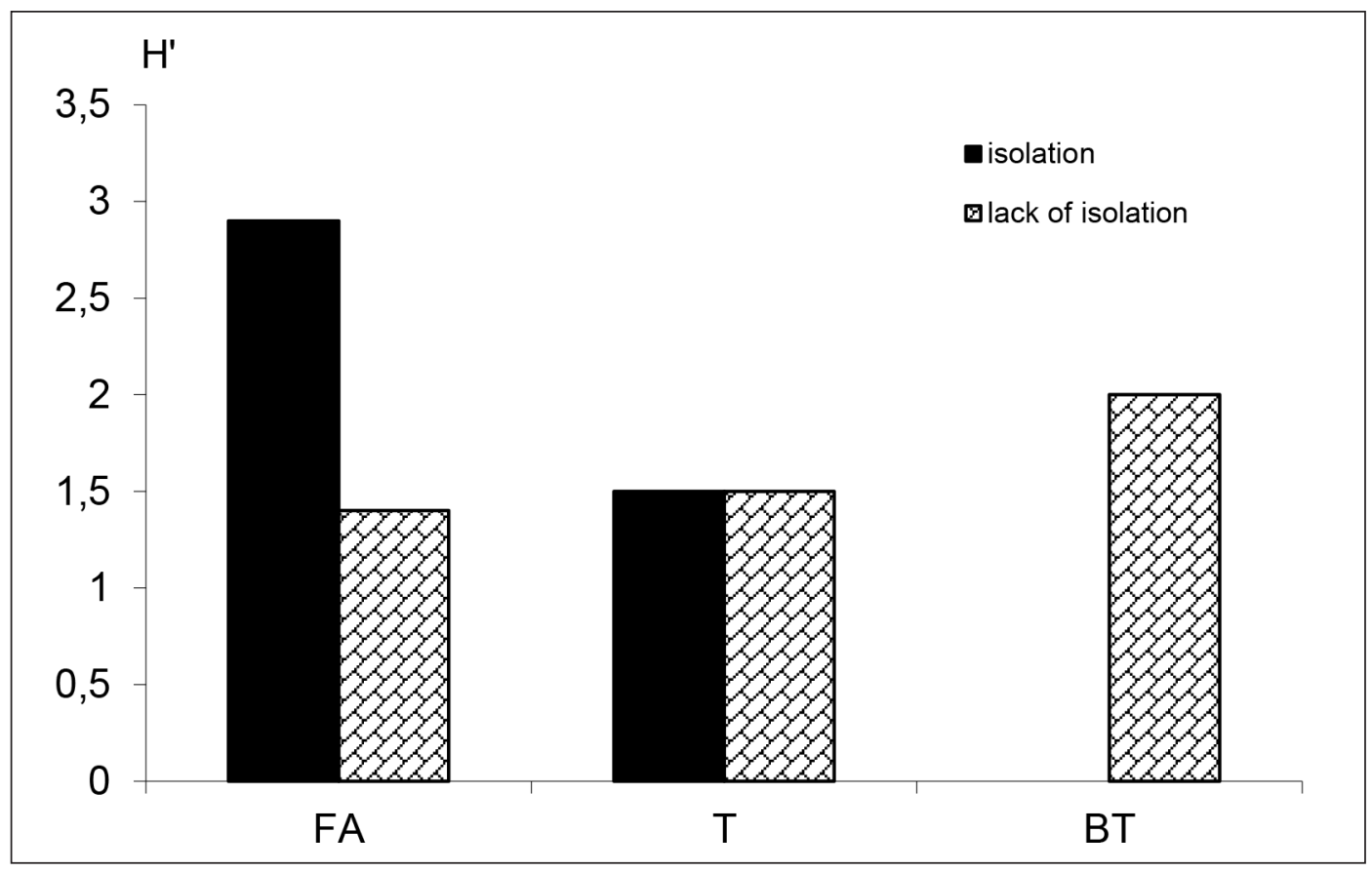

Fig. 4. Shannon-Wiener diversity index values $\left(\mathrm{H}^{\prime}\right)$ calculated for invertebrate assemblages of the alder wood fragment (FA), tussocks (T) and between tussocks (BT), when the water between them was present (isolation) and in the absence of it (no isolation).

During the flood periods, the largest variation is characterized by the aggregation of invertebrates in the alder wood fragment $(\mathrm{p}=0.05)$, while in non-isolation - in areas between tussocks (Fig. 4). The balanced diversity of invertebrate assemblages in the alder tussocks is noteworthy (Fig. 4).

There was no significant effect of the distance from the alder wood fragment on the diversity of invertebrate assemblages on tussocks, regardless of the presence or absence of tussock isolation (isolation
- $\mathrm{H}=4.7, \mathrm{p}=0.45$; no isolation - $\mathrm{H}=9.03$, $\mathrm{p}=0.11$ ) or their size (isolation $-\mathrm{H}=8.08$, $\mathrm{p}=0.1$; no isolation $-\mathrm{H}=6.2, \mathrm{p}=0.2$ ).

\subsection{Artificial tussocks}

The average noted catchings on artificial tussocks, with a surface area corresponding to the average surface area of natural tussocks ("large tussocks") were higher than on tussocks nearly 3 times smaller ("small tussocks"), regardless of the degree of isolation (Table 2).

Table 2. Average catchings (number of individuals/day/trap) of invertebrates on "large" and "small" artificial tussocks, isolated and non-isolated by water.

\begin{tabular}{lcc}
\hline & "Large" artificial tussocks & "Small” artificial tussocks \\
\hline Water between tussocks & $0.2 \pm 0.06^{\mathrm{a}}$ & $0.02 \pm 0.01^{\mathrm{d}}$ \\
No water between tussocks & $0.7 \pm 0.06^{\mathrm{b}, \mathrm{c}}$ & $1.2 \pm 0.05$ \\
\hline
\end{tabular}

a - significant differences in catchings on "large" and "small" isolated tussocks, p=0.003

b - significant differences in catchings on "large" and "small" non-isolated tussocks, p=0.05

c - significant differences in catchings on "large" isolated and non-isolated tussocks, $\mathrm{p}=0.05$

$\mathrm{d}$ - significant differences in catchings on "small" isolated and non-isolated tussocks, $\mathrm{p}=0.05$ 


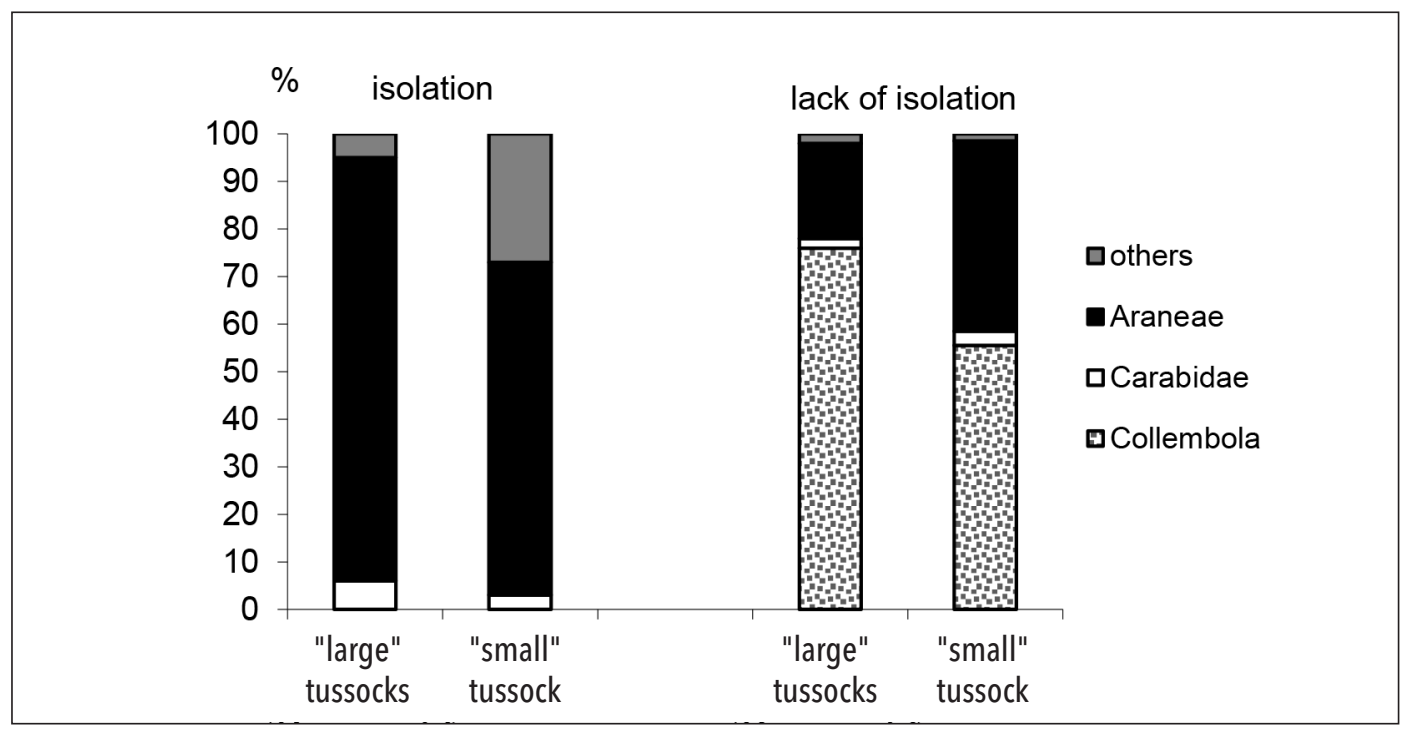

Fig. 5. The share of taxa (see Methods) in invertebrates assemblages penetrating artificial tussocks: "large" (with an area corresponding to the average surface of natural tussocks) and "small" (with an area 3 times smaller than the surface of natural tussocks), when water was present between them and in the absence of it.

On artificial tussocks, clear differences in taxa participation in invertebrate assemblages have been observed, based on the degree of isolation (Fig. 5).

Rantalainen et al. (2005), found that the colonization of the fragments of the environment by soil invertebrates was independent of either the size of the colonized areas or the distance between them, regardless of the degree of isolation. Similarly, in previous studies, invertebrate catchings on particular tussocks did not depend on the distance from the alder wood fragment. It appears that many factors may have influenced the results presented. One of the most important is the mobility of invertebrates. In the study, traps were used, which resulted in catching mainly epigeic, highly mobile animals. It also appears that the water surrounding the alder tussocks is not a barrier to most invertebrates (Collembola, Araneae, Carabidae). The results suggest that the alder wood fragment is the "source" of migrating invertebrates. Based on the catchings and diversity of invertebrates recorded during the period when the tussocks were not isolated, it is likely that the migrating animals did not return to the alder wood fragment. This could have been caused by several factors. For example, for isopods, mortality was an important factor, mainly due to a decrease in food resources (Stachurski 1968). The number of saprophagous invertebrates may have been influenced by the presence and mobility of the potential predators (Guillemain, Loreau and Daufresne 1997; Ferguson and Joly 2002; Wise 2004).

It can also be assumed, that invertebrates are constantly relocating from tussock to tussock, regardless of the factors in work. The evidence would be that invertebrates can be caught on artificial tussocks, which act as "stops" between the next trips. The vicinity of other tussocks also cannot be forgotten. Perhaps, the adjacent tussocks are of greater importance to invertebrates than the distant alder wood fragment. The results thus prompt further research.

\section{Bibliography}

Ferguson, Steven, and Damien Joly. 2002. "Dynamics of springtail and mite populations: the role of density dependence, predation, and weather." Ecological Entomology 27(5): 565-573. https://doi.org/10.1046/j.13652311.2002.00441.x. 
Guillemain, Matthieu, Michel Loreau, and Tanguy Daufresne. 1997. "Relationships between the regional distribution of carabid beetles (Coleoptera, Carabidae) and the abundance of their potential prey." Acta Ecologica 18(4): 465-483. https://doi.org/10.1016/S1146609X(97)80035-5.

Hutcheson, Kermit. 1970. "A test for comparing diversities based on the Shannon formula." Journal of Theorethical Biology 29: 151-154.

Olejniczak, Izabella. 1998. "The carabid communities of natural and drained peatlands in the Biebrza Valley, NE Poland." Polish Journal of Ecology 46(3): 243-260.

Rantalainen, Minna-Liisa, Hannu Fritze, Jari Haimi, Taina Pennanen, and Heikki Setälä. 2005. "Colonisation of newly established habitats by soil decomposer organisms: the effect of habitat corridors in relation to colonization distance and habitat size." Applied Soil Ecology 28(1): 67-77. https://doi. org/10.1016/j.apsoil.2004.06.004.

Shannon, Claude, and Wiliam Wiener. 1963. The mathematical theory of communication. Urbana: University of Illinois Press.

Stachurski, Antoni. 1968. "Emigration and mortality rates and food-shelter conditions of Ligidium hypnorum L. (Isopoda)." Ekologia Polska ser. A: 445-459.

Wise, David H. 2004. "Wandering spiders limit densities of a major micro-detrivore in the forest- floor food web." Pedobiologia 48(2): 181-188. https://doi.org/10.1016/j.pedobi.2003.12.001. 